\title{
Unilateral Variation in the Origin of the Inferior Alveolar and Buccal Arteries: A Case Report
}

\author{
Variación Unilateral en el Origen de las Arterias Alveolar Inferior y Bucal: Reporte de un Caso
}

I. Velasco; R. Soto; R. García \& G. Sepúlveda

VELASCO, I.; SOTO, R.; GARCÍA, R. \& SEPÚLVEDA, G. Unilateral variation in the origin of the inferior alveolar and buccal arteries: A case report. Int. J. Morphol., 29(3):927-929, 2011.

SUMMARY: The maxillary artery (MA) is one of the terminal branches of the external carotid artery (ECA) and is located in the infratemporal fossa (IF). Some of the branches in this region are the inferior alveolar artery (IAA) and the buccal artery (BA), both descending branches. Here, we report an unusual unilateral origin of the IAA and the BA from a common trunk directly from the ECA. We conducted a routine dissection of both IF in a 54-year-old hispanic male cadaver. Fixed with Universidad de los Andes ${ }^{\circledR}$ conservative solution and red latex for vascular filling. On each side, the MA is observed superficially located over the lateral pterygoid muscle. On the right side, the IAA and the BA originate from a common trunk from the ECA approximately 5 mm prior to the bifurcation into their terminal branches. On the left side, the IAA originates from the MA that is immediately next to its origin, making a common trunk with the pterygoid branches. Knowing the morphology of the MA and its branches at the IF is important for oral and maxillofacial surgery procedures; and any variation in the origin or course of these arteries may result in the patient's increased morbidity during some invasive procedure in the area.

KEY WORDS: Anatomical variations; Inferior alveolar artery; Buccal artery; Maxillary artery; Infratemporal fossa.

\section{INTRODUCTION}

The maxillary artery (MA) is one of the terminal branches of the external carotid artery (ECA), and constantly originates from the latter in the parotid region, surrounding from behind the neck of the condyle of mandible, and entering into the depth of the infratemporal fossa (IF), crossing the retrocondilar buttonhole (Juvara) together with the auriculotemporal nerve and the maxillary vein (Rouvière \& Delmas, 2005). Here it reaches the lateral pterygoid (LP) muscle --its satellite muscle-- where there can be variations according to its relationship, and the presence of a superficial variety first outlines the lower edge of the inferior fascicle of the LP and then its lateral face. Whereas, in the deep variety, the MA goes between both LP fascicles then outlining the lateral face (Figun \& Garino, 2002). Studies of the MA topography in the IF (Ortug \& Moriggl, 1991; Bergmann et al., 1988) have indicated that the superficial variety is more prevalent $(55 \%-70 \%)$ in relation to the deep variety $(30 \%-45 \%)$.

Inside the IF, the MA delivers most of its collaterals. Some of the branches in this region include the inferior alveolar artery (IAA) and the buccal artery (BA), both branches descending from the MA. The IAA, in conjunction with the homonymous vein and nerve, makes up the inferior alveolar neurovascular bundle, which goes into the mandibular foramen, and its purpose is to innervate and irrigate the soft bone and cortical tissue of the mandibular body and alveolar processes, the mandibular teeth, and such soft structures as the periodontium, the oral vestibule mucosa and the integument of the lower chin and lip region. On the other hand, the BA goes from its origin toward the buccinator muscle in order to irrigate the soft structures of the cheek (Rouvière \& Delmas).

Both the IAA and the BA share a fairly constant origin, but it has been reported by Jergenson et al. (2005) and Khaki et al. (2005) its origin from the ECA. In this paper, therefore, we report an unusual unilateral origin for the IAA and the BA from a common trunk directly from the ECA. 


\section{CASE REPORT}

During a routine dissection for the integrated morphology course for the study of the head and neck, intended for dentistry students at the Universidad de Los Andes (Chile), a single unilateral origin was found for the IAA and the BA. The finding was in the cadaver of a 54year-old hispanic man without any facial deformations, trauma or surgical scars in the zone, with a partially edentulous maxilla and mandible. The cadaver was previously fixed with Universidad de los Andes® conservative solution, and arterial vascular filled with red latex.

Access to the IF was done by removing the zygomatic bone and reflecting the masseter muscle, leaving exposed that ramus of the mandible which corresponds to the lateral wall of the IF. Then by carefully using a handsaw, the branch was cut and the condyle of the mandibular fossa is disarticulated, carefully saving the inferior alveolar neurovascular bundle both at the entrance through the mandibular foramen and along its way through the mandibular canal. The right-hand side MA was found in its superficial variety in relation to the lateral pterygoid muscle. A normal distribution of the mandibular division of the trigeminal nerve was also found. Yet, tracing the origin of the IAA, we observed the formation of a common trunk with the BA, and this arterial trunk starts from the ECA, about $5 \mathrm{~mm}$ prior to its bifurcation into terminal branches in the parotid region (Fig. 1). The IAA on the opposite side developed from the MA and also appeared in its superficial variety.

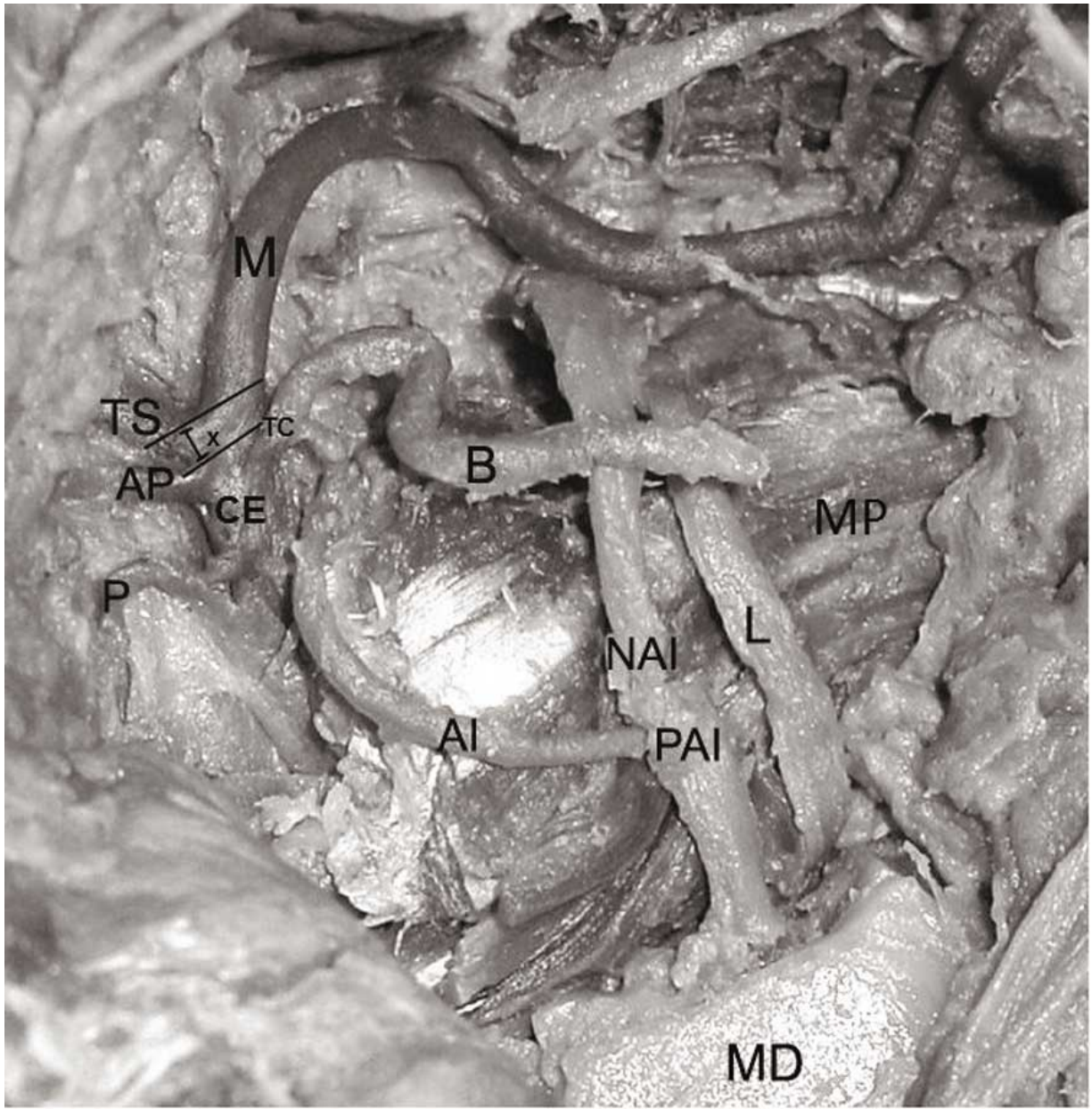

Fig.1. Dissection of right IF. CE: external carotid artery; M: maxillary artery; TS: temporal superficial artery; AI: inferior alveolar artery; B: buccal artery; TC: common trunk of inferior alveolar artery and Buccal artery; X: distance between terminals of external carotid artery and common trunk; AP: auricular posterior artery; P: parotid artery; NAI: inferior alveolar nerve; L: lingual nerve; PAI: inferior alveolar neurovascular bundle; MD: mandible; MP: medial pterygoid muscle.

\section{DISCUSSION}

Knowing the morpho$\log y$ of the MA and its branches at the IF is important for oral and maxillofacial surgery procedures. Some of its important branches, from the surgical point of view, include deep temporal arteries, the masseterian artery, the BA posterior superior alveolar arteries, and the IAA. The way of the latter through the IF is variable, with a fairly constant origin from the MA. In two reported cases, Jergenson et al. and Khaki et al. observe an origin at the ECA. And, in this case in particular, developing a common trunk with the BA.

On the other hand, the inferior alveolar nerve (IAN) goes down next to the IAA in the IF. Blocking the IAN is one of the most frequently used anaesthetic techniques in dentistry. It is also the technique with the highest intravascular injection probability for up to $20 \%$ of cases 
concerned (Frangiskos et al., 2003; Malamed, 2006). Any variation in the origin or path of the IAA may predispose a patient to higher morbidity during mandibular block anesthesia and invasive procedures in that region.

VELASCO, I.; SOTO, R.; GARCÍA, R. \& SEPÚLVEDA, G. Variación unilateral en el origen de las arterias alveolar inferior y bucal: Reporte de un caso. Int. J. Morphol., 29(3):927-929, 2011.

RESUMEN: La arteria maxilar (AM) es una rama terminal de la arteria carótida externa (ACE), y se ubica en la región infratemporal (RI). Algunas de sus ramas en esta región son la arteria alveolar inferior (AAI) y la arteria bucal (AB), ambas ramas descendentes. En este trabajo informamos de un inusual origen unilateral de la AAI y de la AB a partir de un tronco común desde la ACE. Se realizó una disección de rutina de ambas regiones infratemporales en un cadáver de 54 años, sexo masculino, caucásico. Fijado con solución conservadora Universidad de los Andes® y repleción vascular con látex rojo. A cada lado, se observa la AM en ubicación superficial sobre el músculo pterigoideo lateral. Al lado derecho, la AAI y la AB se originan de un tronco común desde la ACE aproximadamente 5 mm antes de la bifurcación en sus ramas terminales. Al lado izquierdo la AAI se origina de la AM inmediato a su origen, formando un tronco común con los ramos pterigoideos. El conocimiento de la morfología de la AM y de sus ramas en la RI es de importancia en procedimientos odontológicos, de cirugía oral y maxilofacial. Por lo que cualquier variación en el origen o trayecto de estas arterias puede predisponer a un paciente a una mayor morbilidad durante algún procedimiento invasivo en la zona.

PALABRAS CLAVE: Variaciones anatómicas; Arteria alveolar inferior; Arteria buccal; Arteria maxilar; Región infratemporal.

\section{REFERENCES}

Bergman, R. A.; Thompson, S. A.; Afifi, A. K. \& Saadeh, F. A. Compendium of human anatomic variation: text, atlas, and world literature. Baltimore, Urban \& Schwarzenberg Inc., 1988. pp.64-6.

Figun, M. E. \& Garino, R. Anatomía odontológica: funcional y aplicada. $2^{\text {a }}$ edición. Buenos Aires, El Ateneo, 2002. p.79-80.

Frangiskos, F.; Stavrou, E.; Merenditis, N.; Tsitsogianis, H.; Vardas, E. \& Antonopoulou, I. Incidence of penetration of a blood vessel during inferior alveolar nerve block. Br. J. Oral Maxillofac. Surg., 41(3):188-9, 2003.

Jergenson, M. A.; Norton, N. S.; Opack, J. M. \& Barritt, L. C. Unique origin of the inferior alveolar artery. Clin. Anat., 18(8):597-601, 2005.

Khaki, A. A.; Tubbs, R. S.; Shoja, M. M.; Shokouhi, G. \& Farahani, R. M. A rare variation of the inferior alveolar artery with potential clinical consequences. Folia Morphol., 64(4):345-6, 2005.

Malamed, S. F. Manual de anestesia local. $5^{\text {a }}$ Ed. St. Louis, Mosby, 2006. pp.228-9.

Ortug, G. \& Moriggl, B. The topography of the maxillary artery within the infratemporal fossa. Anat. Anz., 172(3):197-202, 1991.
Rouvière, H. \& Delmas, A. Anatomía Humana, descriptiva, topográfica y funcional. $11^{\text {a }} \mathrm{Ed}$. Barcelona, Masson, 2005. Tomo I. p.226-8.

Correspondence to:

Dr. Ignacio A. Velasco

Department of Morphology

Universidad de Los Andes

Av. San Carlos de Apoquindo 2.200

Santiago

CHILE

Email: iavelasco@miuandes.cl

Received: 29-05-2011

Accepted: 28-06-2011 